Int. J. Electrochem. Sci., 15 (2020) 3955 - 3968

International Journal of

ELECTROCHEMICAL

SCIENCE

$\underline{\text { WWW.electrochemsci.org }}$

\title{
Effect of Heat Treatment on Thermal Expansion Behavior and Corrosion Resistance of Martensitic Stainless Steel Manufactured by Submerged Arc Welding
}

\author{
Xinyue Wang ${ }^{1}$, Jihui Wang ${ }^{1}$, Zhiming Gao ${ }^{1, *}$, Wenbin $H u^{1,2, *}$ \\ ${ }^{1}$ Tianjin Key Laboratory of composite \& Functional Materials, School of Materials Science and \\ Engineering, Tianjin University, Tianjin, 300072, China \\ ${ }^{2}$ Key Laboratory of Advanced ceramics and Machining Technology (Ministry of Education), Tianjin \\ University, Tianjin, 300072, China \\ *E-mail: gaozhiming@tju.edu.cn; wbhu@tju.edu.cn
}

doi: $10.20964 / 2020.05 .31$

Received: 3 February 2020 / Accepted: 11 March 2020 / Published: 10 April 2020

The martensitic stainless steel surfacing layer was deposited on the $\mathrm{H} 13$ steel using submerged arc welding (SAW). The effect of the tempering conditions $\left(350{ }^{\circ} \mathrm{C} \sim 650{ }^{\circ} \mathrm{C}\right.$ for $2 \mathrm{~h}$ and $450{ }^{\circ} \mathrm{C}$ for $0.5 \mathrm{~h} \sim$ $4 \mathrm{~h}$ ) on the microstructure, thermal expansion behavior and corrosion resistance was systematically analyzed. The results indicated that tempering led to the transformation of the residual austenite and coarse martensite in the as-welded sample to the fine tempered martensite and carbides $\left(\mathrm{Fe}_{3} \mathrm{C}-450{ }^{\circ} \mathrm{C} / 0.5\right.$ $\mathrm{h}$ and $\mathrm{M}_{7} \mathrm{C}_{3}$-other conditions). An optimal fusion between the $\mathrm{H} 13$ steel and surfacing layer was obtained in all cases, with no appreciable cracks. Relative thermal expansion $\left(\Delta \mathrm{L} / \mathrm{L}_{0}\right)$ and thermal expansion coefficient (CTE) were observed to increase at first due to the reduction in the welding defects, followed by a decrease due to the phase transition and microstructure coarsening on increasing the tempering temperature and duration. The thermal expansion behavior closest to that of the H13 steel was obtained at $450{ }^{\circ} \mathrm{C}$ for $2 \mathrm{~h}$, along with a better thermal stability and lower cracking sensitivity. Furthermore, the surfacing layer with a high alloy content exhibited much better corrosion resistance than the H13 steel. After tempering at or above $450{ }^{\circ} \mathrm{C}$ for $2 \mathrm{~h}$, the corrosion resistance of the surfacing layers was noted to be higher than the as-welded sample. The corrosion resistance enhanced further on increasing the tempering temperature and duration, which was dependent on the even phase composition and homogeneous microstructure as well as decreased welding defects and grain boundaries. The maximum $R_{\text {ct }}$ value $\left(1.961 \times 10^{5} \Omega \cdot \mathrm{cm}^{2}\right)$ was obtained at $650{ }^{\circ} \mathrm{C}$ for $2 \mathrm{~h}$, thus, suggesting an optimal corrosion resistance.

Keywords: H13 steel, submerged arc welding, martensitic stainless steel, tempering, thermal expansion, corrosion resistance. 


\section{FULL TEXT}

(C) 2020 The Authors. Published by ESG (www.electrochemsci.org). This article is an open access article distributed under the terms and conditions of the Creative Commons Attribution license (http://creativecommons.org/licenses/by/4.0/). 